\title{
Novel Cationic 2-Phenylpyridine-based Iridium(III) Complexes Bearing an Ancillary Phosphine Ligand: Synthesis, Photophysics and Crystal Structure
}

\author{
Ai-Feng Ma, Hoe-Joo Seo, Sung-Ho Jin, ${ }^{\dagger}$ Ung Chan Yoon, Myeong Ho Hyun, Sung Kwon Kang, ${ }^{\ddagger}$ and Young-Inn Kim ${ }^{\ddagger}$ \\ Department of Chemistry, Ptisan National Lniversity, Busan 609-735, Korea \\ ${ }^{\dagger}$ Department of Chemistrv Education and Interdisciplinary Program of Advanced Information and Displav Materials, \\ Pusan National University, Busan 609-735, Korea. "E-mail: vikimapusan.ac.kr \\ ${ }^{\ddagger}$ Department of Chemistr. Chungham National Univensity. Deajeon $305-76+$. Korea \\ Received August 19, 2009, Accepted October 5, 2009
}

\begin{abstract}
Three novel phosphorescent 2-phenylpyridine-based iridium(III) complexes, [(ppy) $\left.\operatorname{Ir}\left(\mathrm{P}^{\wedge} N\right)\right] \mathrm{PF}_{0}(1)_{2}\left[\left(\mathrm{dtppy}_{2} \operatorname{Ir}\left(\mathrm{P}^{\wedge} \mathrm{N}\right)\right]\right.$ $\mathrm{PF}_{\circ}(2)$, and $\left[(d \mathrm{fm} p \mathrm{py})_{2} \operatorname{Ir}\left(\mathrm{P}^{\wedge} \mathrm{N}\right)\right] \mathrm{PF}_{\mathrm{o}}(3)$, where $\mathrm{P}^{\wedge} \mathrm{N}=2-[$ (diphenylphosphino)methyl $]$ py ridine (dppmp), were synthesized and characterized. The absontion, photoluminescence, cyclic voltammetry and themal stability of the compleves were investigated. The complexes showed bright blue luminescences at wavelengths of $448 \sim 500 \mathrm{~nm}$ at room temperature in $\mathrm{CHCl}_{3}$ and revealed that the $\pi$-acceptor ability of the phosphorous atom in the ancillary dppmp ligand plays an important role in tuning emission color resulting in a blue-shift emission. The single crystal structure of [ (dfmppy) $\left.\operatorname{Ir}\left(\mathrm{P}^{\wedge} \mathrm{N}\right)\right] \mathrm{PF}_{\mathrm{b}}$ was determined using $\mathrm{X}$-ray crystallography. The iridium metal center adopts a distorted octahedral structure coordinated to two dfmppy and one dppmp ligand, showing cis $\mathrm{C}-\mathrm{C}$ and trans $\mathrm{N}-\mathrm{N}$ chelate dispositions. There is a $\pi$ - $\pi$ overlap between $\pi$ electrons delocalized in the difluorophenyl rings.
\end{abstract}

Key Words: Iridium complex, Cationic heteroleptic cyclometalated complex, Phosphine ligand, Blue phosphorescence

\section{Introduction}

Phosphorescent iridium(III) complexes have been an active research area for application in organic light-emitting diodes (OLEDs) since Baldo ef al. ' reported high-efficiency green phosphorescent OLEDs at room temperature based on factris(2-phenylpyridine)iridium(III) [Ir(ppy) 3 ]. Iridium(III) complexes are regarded as the most effective phosphorescent materials given their relatively long-lived excited state and high quantum efficiency resulting from effective utilization of both singlet and triplet excited states for light emission. As such. they are often used as light emitters in electroluminescence displays. Red green. and blue emissions with good color purity and high efficiencies are required for full-color display applications. Although great successes have been achieved in the development of red ${ }^{2}$ and green ${ }^{3}$ iridium emitters. pure blue emission materials ${ }^{4}$ are still rare due to the wide gap and relatively low efficiency.

In 2-phenylpyridine (ppy)-based iridium(III) complexes. the emission is believed to originate from mixed triplet states possessing both intraligand (IL) ${ }^{3} \pi-\pi^{*}$ and metal-to-ligand charge transfer $\left({ }^{3} \mathrm{MLCT}\right)$ characters or states with greater contributions from ${ }^{3} \mathrm{MLCT}$. From the view point of ligand chromophores. the lowest unoccupied molecular orbital (LUMO) and highest occupied molecular orbital (HOMO) energy levels are mainly located at the pyridyl portion and phenyl segment of the ppy ligand. respectively. which are affected by the electronic state of the ligand. In principle. in order to blue-shift the emission wavelength in iridium(III) complexes. the LUMO-HOMO energy gap should be increased. thereby stabilizing the HOMO and/ or destabilizing the LUMO energy levels. Recently, [(dfppy) Ir (pic)]. where dfppy $=2-(2.4$-difuorophenyl $)$ pyrridine and pic $=$ picolinate. FIrpic . was reported and used as a blue emission phosphor in an electroluminescence device. The electron-withdrawing $\mathrm{F}$ atoms were introduced in the phenyl ring in the ppy ligand, resulting in stabilization of the HOMO energy level, and the picolinate ligand finely tuned the enission color in the FIrpic. The emission wavelength was tuned by modification of the ppy ligand as well as by introducing an adequate ancillary ligand.

As an effort of a development of blue emission materials. herein we report the synthesis and characterization of three cationic heteroleptic cyclonetalated iridiun(III) complexes: [(ppy) $\left.\operatorname{Ir}\left(\mathrm{P}^{\wedge} \mathrm{N}\right)\right] \mathrm{PF}_{6}(\mathrm{l}):\left[(\mathrm{dfppy})_{2} \operatorname{Ir}\left(\mathrm{P}^{\wedge} \mathrm{N}\right)\right] \mathrm{PF}_{6}(2):\left[\left(\mathrm{dfmppy}_{2}\right)_{2} \operatorname{Ir}\left(\mathrm{P}^{\wedge} \mathrm{N}\right)\right]$ $\mathrm{PF}_{6}$ (3). The electron-donating $-\mathrm{CH}_{3}$ group in the pyridyl moiety and/or the electron-withdrawing $\mathrm{F}$ atom in the phenyl moiety were substituted. varying the electronic state in the ppy ligand; the 2-[(diphenylphosphino)methyll]pyridine $\left(\mathrm{P}^{\wedge} \mathrm{N}\right)$ was used as an ancillary ligand. The $\pi$-accepting character of the phosphine group is expected to increase the associated MLCT energy level in anticipation of a blue-shift emission. ${ }^{6}$

\section{Experimental}

Materials and Synthesis. All reagents and solvents were commercially obtained from Sigma-Aldrich Chemicals or Acros Organics and used without further purification with an exception of tetrahyddrofuran (THF), which was distilled from sodium/benzophenone under nitrogen.

2-(2.4-Difluorophenyl)-4-methylpyridine (dfinppy) and 2(2.4-difluoro)phenylpyridine (dfppy) were prepared from the reaction of 2.4-difluorophenylboronic acid with 2-brono-4-methylpy ridine and 2-bromopy ridine, respectively. using tetrakis (triphenylphosphine)palladiun( $(0)$ as a catalyst in THF ? 2-[(Diphenỵlphosphino)methỵl]py ridine (dppmp) was șynthesized 
from the reaction of $n$-butyllithum, 2-picoline. and diphenylphosphinochloride using standard Schlenk technique. and the product was directly used for the next step without further purification.

$\left.\left.\left[\left(\mathrm{C}^{\wedge} \mathbf{N}\right)_{2} \mathrm{Ir}(\mathrm{d}) p \mathrm{pm}\right)\right)\right] \mathrm{PF}_{6}$ complexes: General Procedure. $\mathrm{Cy}$ clometalated iridinium(III) $\mu$-clloro-bridged dimers. $\left[\left(\mathrm{C}^{\wedge} \mathrm{N}\right)\right.$ 二 $\operatorname{Ir}(\mu-\mathrm{Cl})]_{乏}$, where $\mathrm{C}^{\wedge} \mathrm{N}=$ ppy. dfppy. and dfmppy. were prepared from the reaction of $\mathrm{IrCl}_{3} \cdot 3 \mathrm{H}_{2} \mathrm{O}$ with the main ligand $\left(\mathrm{C}^{\wedge} \mathrm{N}\right)$ in a 3:1 mixture of 2-ethoxyethanol and water at $125^{\circ} \mathrm{C}$ for $2+\mathrm{h}$. The dimeric iridium(III) complex. $\left[\left(\mathrm{C}^{\wedge} \mathrm{N}\right)_{\Sigma} \mathrm{Ir}(\mu-\mathrm{Cl})\right]_{2}(0.5 \mathrm{mmol})$. $\mathrm{Na}_{2} \mathrm{CO}_{3}(5.0 \mathrm{mmol})$ and dppmp (3.0 eq) were dissolved in 30.0 $\mathrm{mL}$ of 2-ethoxy'ethnol and stirred at $130^{\circ} \mathrm{C}$ under nitrogen for $24 \mathrm{~h}$. The cooled mixture was poured into water and extracted with $\mathrm{CH}_{2} \mathrm{Cl}_{2}(50 \mathrm{~mL} \times 3)$ and dried over anhydrous magnesium sulfate. The product. $\left[\left(\mathrm{C}^{\wedge} \mathrm{N}\right)_{\mathrm{Z}} \operatorname{Ir}(\mathrm{dppmp})\right] \mathrm{Cl}$, was purified by column chromatography on silica gel using $n$-hexane $/ \mathrm{CH}_{2} \mathrm{Cl}_{2}$ as an eluent. The purified chloride salts were reacted with $\mathrm{NH}_{4} \mathrm{PF}_{6}$ in methanol. refluxing for $1 \sim 2 \mathrm{~h}$. The products were collected by filtration and washed with methanol. The products were characterized by ${ }^{1} \mathrm{H}-\mathrm{NMR}$ and elemental analyses. Elementary analyses were performed at the Korean Basic Science Center.

[(ppy) $\mathbf{I r}(\mathbf{d p p m p )})] \mathrm{PF}_{6}(\mathbf{1}),{ }^{1} \mathrm{H}-\mathrm{NMR}\left(\mathrm{CDCl}_{3}\right): \hat{\delta}$ (ppm) 8.55 $(\mathrm{d} . J=5.4 \mathrm{~Hz}, \mathrm{IH}) .8 .27$ (d. $J=7.5 \mathrm{~Hz} . \mathrm{IH}): 7.98(\mathrm{t} . J=7.5 \mathrm{~Hz}$. $\mathrm{lH}): 6.80-8.00(\mathrm{~m}, 23 \mathrm{H}): 6.62$ (t. $J=10.5 \mathrm{~Hz}, 2 \mathrm{H}): 6.53$ (d. $J=$ $6.9 \mathrm{~Hz} .1 \mathrm{H}) ; 6.11(\mathrm{dd} . J=7.2 .4 .8 \mathrm{~Hz}, 1 \mathrm{H}) ; 4.99(\mathrm{dd} . J=18.0$, $12.3 \mathrm{~Hz}, 1 \mathrm{H}): 4.25$ (dd, $J=17.4 .6 .6 \mathrm{~Hz}, 1 \mathrm{H})$. Anal. Calcd for $\mathrm{C}_{4}\left(\mathrm{H}_{32} \mathrm{~F}_{6} \mathrm{IrN}_{3} \mathrm{P}_{2}:\right.$ C. $52.06 ; \mathrm{H}, 3.50:$ N. 4.55. Found: C. $52.72: \mathrm{H}$, 3.28: N. 4.39.

[(dfppy) $\left.\left.{ }_{2} \operatorname{Ir}(\mathbf{d p p}) \operatorname{mp}\right)\right] \mathbf{P F}_{6}(\mathbf{2}) .{ }^{1} \mathrm{H}-\mathrm{NMR}\left(\mathrm{CDCl}_{3}\right): \hat{\delta}(\mathrm{ppm}) 8.53$ (d. $J=3.9 \mathrm{~Hz}, 1 \mathrm{H}) ; 8.33$ (m. $2 \mathrm{H}): 8.06(\mathrm{~m} .2 \mathrm{H}): 7.84(\mathrm{~s}, 2 \mathrm{H})$; $7.59(\mathrm{~m} .+\mathrm{H}): 7.4+(\mathrm{t} . J=6.0 \mathrm{~Hz}, 2 \mathrm{H}): 7.25(\mathrm{~m} .1 \mathrm{H}): 7.06(\mathrm{~d}$. $J=6.6 \mathrm{~Hz} .1 \mathrm{H}$ ): 6.97 (s. $4 \mathrm{H}): 6.62(\mathrm{~m} .5 \mathrm{H}): 5.93$ (dd. $J=2.4$. $9.6 \mathrm{~Hz}, 1 \mathrm{H}): 5.55(\mathrm{~m}, \mathrm{lH}): 5.00(\mathrm{~m}, 1 \mathrm{H}) ; 4.36$ (s. 1H). Anal. Calcd for $\mathrm{C}_{40} \mathrm{H}_{28} \mathrm{~F}_{10} \mathrm{IrN}_{3} \mathrm{P}_{2}: \mathrm{C} .48 .29: \mathrm{H}, 2.84: \mathrm{N}, 4.22$. Found: C. 48.56 ; H. $2.42 ;$ N. 4.09 .

[(dfmppy) $\left.)_{2} \mathbf{I r}(\mathbf{d p p m p})\right] \mathbf{P F}_{6}(3) .{ }^{\mathrm{l}} \mathrm{H}-\mathrm{NMR}\left(\mathrm{CDCl}_{3}\right): \delta(\mathrm{ppm})$ 8.32 (d. $J=6.3 \mathrm{~Hz}, \mathrm{lH}): 8.28$ (d. J $=7.5 \mathrm{~Hz}, \mathrm{lH}): 8.12$ (s. $\mathrm{lH})$; $8.01(\mathrm{t} . J=7.5 \mathrm{~Hz}, 1 \mathrm{H}): 7.86(\mathrm{~s} .1 \mathrm{H}) ; 7.82(\mathrm{~d} . J=5.7 \mathrm{~Hz}, 1 \mathrm{H})$; 7.60 (t. $J=8.1 \mathrm{~Hz}, 2 \mathrm{H}): 7.5 \mathrm{~L}(\mathrm{~d} . J=6.9 \mathrm{~Hz}, \mathrm{IH}): 7.43(\mathrm{t} . J=5.7$ Hz. $2 \mathrm{H}$ ): 7.20 (t. $J=6.0 \mathrm{~Hz}, \mathrm{lH}): 7.08$ (t. $J=7.5 \mathrm{~Hz}, \mathrm{lH}): 6.97$ $(\mathrm{t} . J=5.1 \mathrm{~Hz}, 2 \mathrm{H}): 6.80(\mathrm{~d} J=5.7 \mathrm{~Hz}, \mathrm{lH}): 6.75(\mathrm{~d} J=6.0 \mathrm{~Hz}$, $1 \mathrm{H}) ; 6.68-6.54(\mathrm{~m},+\mathrm{H}) ; 6.39(\mathrm{~d} . J=5.7 \mathrm{~Hz}, 1 \mathrm{H}) ; 5.95(\mathrm{~d} . J=$ $8.4 \mathrm{~Hz}, 1 \mathrm{H}) ; 5.61$ (n. $1 \mathrm{H}): 4.98(\mathrm{dd}, J=18.6,12.3 \mathrm{~Hz}, 1 \mathrm{H})$; 4.27 (dd. $J=17.7 .6 .6 \mathrm{~Hz}, 1 \mathrm{H}$ ): 2.50 (s. $3 \mathrm{H}$ ): 2.38 (s. $3 \mathrm{H}$ ). Anal. Calcd for $\mathrm{C}_{42} \mathrm{H}_{2} \mathrm{~F}_{10} \mathrm{IrN}_{2} \mathrm{P}_{2}: \mathrm{C}_{2} 49.32: \mathrm{H}, 3.15: \mathrm{N}, 4.11$. Found: C. 49.31; H. 3.57; N, 4.39.

Instruments. The ${ }^{1} \mathrm{H}-\mathrm{NMR}$ spectra were recorded with a Varian Mercury 300 spectrometer with $\mathrm{CDCl}_{3}$ ( ${ }^{\mathrm{j}} \mathrm{H}$ : ô $7.27 \mathrm{ppm}$ ) as the solvent. The UV-Vis absorption and photoluminescence (PL) spectra were measured by a Jasco V-570 UV-Vis spectrophotometer and a Hitachi F-4500 fluorescence spectrophotometer. respectively. from 200 to $800 \mathrm{~nm}$. Cyclic voltammetry (CV) experiments were performed on a Bioanalytical Systems CV$50 \mathrm{~W}$ voltammetric analyzer in a $0.1 \mathrm{M}$ solution of tetrabutylammonium tetrafluoroborate $\left(\mathrm{Bu}_{4} \mathrm{NBF}_{4}\right)$ in anhydrous acetonitrile. The Pt disk electrode. $\mathrm{Ag} / \mathrm{AgNO}_{5}(0.1 \mathrm{M})$ electrode and Pt electrode were used as the working, reference and counter electrode, respectively, at a scan rate of $100 \mathrm{mV} / \mathrm{s}$. Thermal analy ses were carried out on a Metler Toledo TGA/DTA 815 analyzer under a nitrogen atmosphere at a heating rate of $10^{\circ} \mathrm{C} / \mathrm{min}$.

Crystallography. The X-ray intensity data were obtained using a Bruker SMART APEX-II CCD diffractometer equipped with graphite monochromated Mo Ka radiation $(\lambda=0.71073 \AA)$ at $295 \mathrm{~K}$. Initial unit cell parameters were obtained from SMART software ${ }^{3}$ Data integration correction for Lorentz and polarization effects. and final cell refinement were performed by SAINTPLUS. ${ }^{9}$ An enpirical absorption correction based on the multiple measurement of equivalent reflections was applied using the program SADABS. Structures were obtained by a combination of the direct methods and difference Fourier syntheses and refined by full matrix least-squares on ${F^{-}}^{2}$, using the SHELXTL." All non-hydrogen atoms were refined anisotropically. Hydrogen atoms were added in calculated positions<smiles>Cc1ccccn1</smiles><smiles>[R1]c1ccc(-c2cc([R2])cc([R])c2)nc1</smiles>

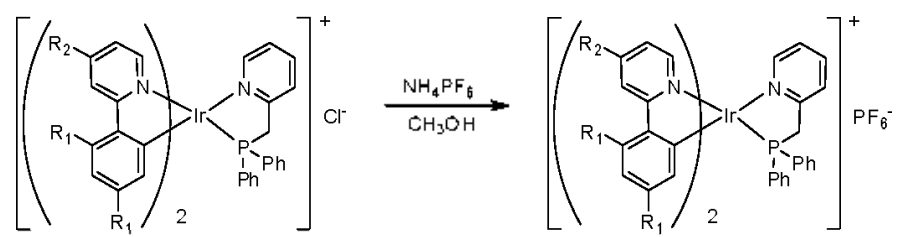

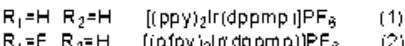

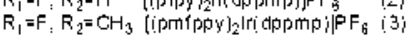

Scheme 1. Synthesis of dppmp and complexes 1,2 and 3. 
(a)

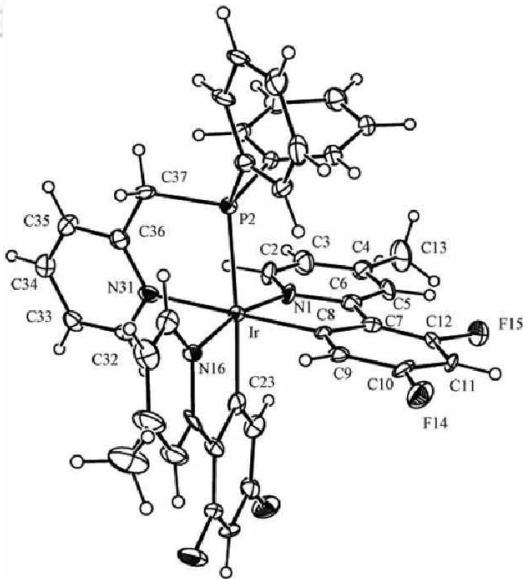

(b)

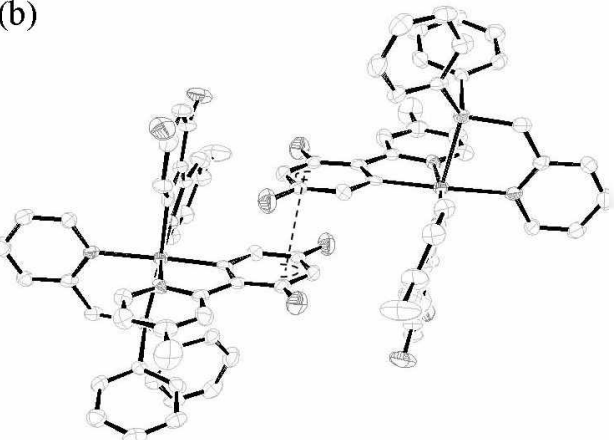

Figure 1. (a) ORTEP drawing of [(dfmppy) $I r($ dppmp)] showing the atom numbering scheme with $30 \%$ probability ellipsoids: Ir-C8 2.021 (7); Ir-Nl 2.030(5); Ir-C23 2.044(7): Ir-N162.077(6): Ir-N31 2.193(6); Ir-P2 2.348(19): C $8-I_{r}-\mathrm{C} 2386.40(3): \mathrm{C} 23-\mathrm{I}_{\mathrm{T}} \mathrm{N} 3193.90(2): \mathrm{C} 8-\mathrm{IT}-\mathrm{P} 2$ 99.38( 19); N31-Ir-P2 80.24(16); NI-Ir-NI6 167.4(2). (b) Crystal packing diagram between two adjacent molecules showing an intemolecular $\pi-\pi$ stacking interaction. The phenyl ... phenyl contact distance is $3.254 \sim 3.718 \AA$

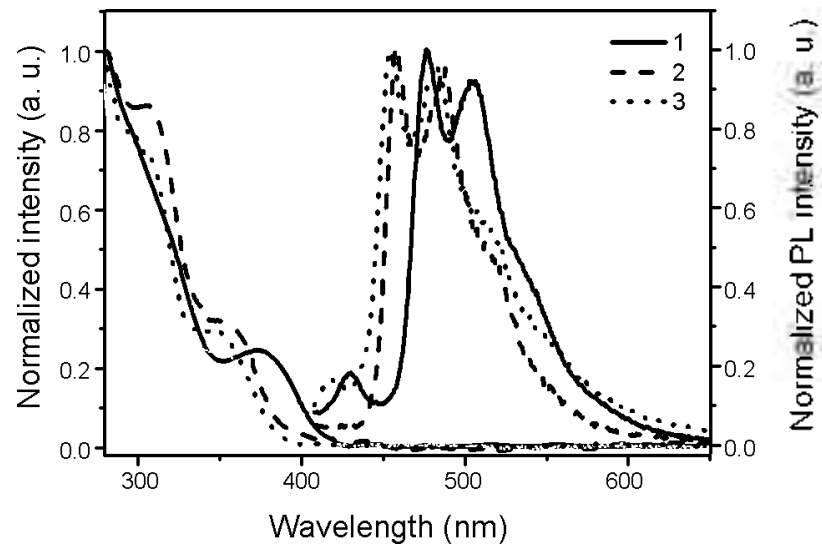

Figure 2. Absorption and photoluminescence spectra of complexes 1,2 and 3 in $\mathrm{CHCl}_{3}$

\section{Results and Discussion}

Synthesis and Structural Characterization. The reaction of 2-picoline and $n$-buty llithum with dipheny lphosphinochloride yielded $2-[($ diphenylphosphino)methyl]pyridine (dppmp), and the phenylpyridine derivatives were made from the Suzuki coupling method. The chloro-bridged dimers. $\left[\left(\mathrm{N}^{\wedge} \mathrm{C}\right) \leq \mathrm{Ir}(\mu-\mathrm{Cl})\right]_{2}$. were prepared through a modified Nonoyama method. ${ }^{\text {l' }}$ The chloro-bridged dimer was used as starting material to yield cationic heteroleptic iridium(III) chloride salts. The $\mathrm{PF}_{6}$ salt was made from the chloride salt, using $\mathrm{NH}_{4} \mathrm{PF}_{6}$ in methanol. The synthetic procedure is shown in Scheme l. The properties of the clloride salts are nearly consistent with those of the $\mathrm{PF}_{\overline{6}}$ salts discussed herein.

The structure was determined from the single crystal of complex 3 obtained from a mixed solvent system $\left(\mathrm{Me}-\mathrm{OH} / \mathrm{CHCl}_{3}\right)$. The ORTEP diagram, including the atomic numbering scheme and packing diagram, are shown in Figure 1. The cry stallographic data follows: $\mathrm{C}_{3 \mathrm{i}} \mathrm{H}_{32} \mathrm{Cl}_{2} \mathrm{~N}_{4} \mathrm{Zn} . \mathrm{H}_{\mathrm{w}}=584.87$. Monoclinic. $P 2_{1} / \mathrm{c}, a=14.108(2) \AA, b=9.4890(16) \AA . c=21.606(4) \AA, \alpha=$ $90.00^{\circ}, \beta=99.930(3)^{\circ}, \gamma^{\prime}=90.00^{\circ}, r^{\prime}=2849.1(8) \mathrm{A}^{3} . Z=4$, $D_{\text {calc }}=1.363 \mathrm{Mg} \mathrm{m}^{-3}, \mu l=1.075 \mathrm{~mm}^{-1}, \theta_{\max }=27.50^{\circ} .23572$ reflections $\left(R_{\text {ut }}=0.0667\right), 65+4$ unique reflections. 333 parameters refined. Good of Fit $=1.061$. Final $R$ indices $[I>2 \sigma(I)]: R_{1}=$ $0.0561 . \mathrm{w} R_{2}=0.1411$. all data: $R_{1}=0.1202 . \mathrm{w} R_{2}=0.1844$.

The iridium metal center adopts a distorted octahedral structure with the trans angles of $167 \sim 176^{\circ}$ coordinated to two dfmppy and one dppma ligand, showing a cis C-C and trans $\mathrm{N}-\mathrm{N}$ chelate disposition which is a coincident mode of the chloride-bridged precursor dimer. ${ }^{13}$ This result indicates that the ancillary ligand (dppma) replaces the chloride ions in the precursor dimer complex in the synthetic reaction.

The Ir-N bond lengths $[2.030(5) \mathrm{A}$ and $2.077(6) \mathrm{A}]$ were within the normal range reported for analogous cyclometalated iridium complexes. ${ }^{1+}$ The $\mathrm{Ir}-\mathrm{C} 23$ bond $[2.04+(7) \mathrm{A}]$ was found to be longer than the Ir-C8 bond [2.021(7) $\AA$ ]. ascribed to the stronger trans influence of the phosphorous atom in the phosphine than the nitrogen atom in the pyridine ring. This trans influence was reported in the $\operatorname{Ir}(\mathrm{tpy})_{3}$ [tpy $=2$-toly'py'ridyl]. in which the Ir-N bond in facial isomer was longer than that in the meridional isomer of the Ir(tpy) z. resulting from the weaker trans influence of the pyridyl group relative to the phenyl group. ${ }^{15}$

The dihedral angle between the difluorophenyl and methylpyridine ring $\mathrm{C} 5-\mathrm{C} 8-\mathrm{C} 7-\mathrm{Cl} 2$, was $4.14^{\circ}$, being almost coplanar. This small distortion is explained by the fact that the $\pi$ electron density of the difluorophenyl group is smaller than that of phenyl ring. Furthermore, there is an interaction between the $\mathrm{C} 5$ hydrogen and F 15 fluorine atom (C5 .F 15:2.223 $\AA$ ). therefore the fluoro-substituted groups contribute less to the steric hindran$\mathrm{ce}^{16}$

The cristal packing diagram [Figure $1-(b)]$ shows a $\pi-\pi$ overlap between the $\pi$ electrons delocalized on the $\mathrm{C} 10, \mathrm{C} 11, \mathrm{C} 12$ atoms in the difluorophenyl ring and the similarly distributed $\pi$ electrons in an adjacent molecule. The distance between the part of the difluorophenyl rings was $3.254 \sim 3.718 \AA$. suggesting a favorable. shared interaction. ${ }^{1 \text { ? }}$

Photophysical Properties. The absorption (UV/Vis) and photoluminescence (PL) spectra in aerated chloroform at room temperature are shown in Figure 2, and the results summarized in Table 1

The absorption bands below $300 \mathrm{nn}$ were tentatively assigned as ${ }^{1}\left(\pi \rightarrow \pi^{*}\right)$ transitions of the phenylpy ridyl-based ligands and the peaks near $350 \sim 375 \mathrm{~nm}$ ascribed as spin-allowed metal- 
Table 1. Photophysical, electrochemical and thernal properties for compleses 1,2 and 3.

\begin{tabular}{|c|c|c|c|c|c|c|c|c|}
\hline Complex & $a_{v_{v} b s}[\mathrm{~nm}]$ & ${ }^{a} \hat{\gamma}_{\text {wertr }}[\mathrm{nm}]$ & ${ }^{b} \Phi_{\mathrm{PL}}$ & ${ }^{c} \mathrm{E}_{1: 2}(\mathrm{v})$ & ${ }^{'} \mathrm{HOMO}(\mathrm{eV})$ & ${ }^{d} \mathrm{E}_{\mathrm{g}}{ }^{\mathrm{ppt}}(\mathrm{eV})$ & ${ }^{\mathrm{E}} \mathrm{LUMO}(\mathrm{eV})$ & ${ }^{f} \mathrm{~T}_{4}\left[{ }^{\circ} \mathrm{C}\right]$ \\
\hline 1 & $281,306,375$ & 470,500 & 0.004 & 0.90 & -5.70 & 2.86 & -2.84 & 370 \\
\hline 2 & $281,303,352$ & 452,481 & 0.007 & 1.19 & -5.99 & 309 & -2.90 & 385 \\
\hline 3 & $277,300,348$ & 448,478 & 0.016 & 1.15 & -5.95 & 3.12 & -2.83 & 370 \\
\hline
\end{tabular}

"Absorption spectra and PL were tested in aerated chloroform solution at $298 \mathrm{~K}$. "PL quantum efficiency was determined using Irippy $)($ bpy $)$. PF $(\mathbb{D}=$ 0.06 ) as a standard. ${ }^{18 a}$ and calculated with a published method. ${ }^{18 \mathrm{~b}}{ }^{\mathrm{H}} \mathrm{HOMO}$ falues were acquired from cyclic foltammetry data, using the onset method. ${ }^{18 \mathrm{c}}$ "Energy band gaps were obtained from the absorption peaks in the film state. " ${ }^{\text {"HOMO }}=-\left(\mathrm{E}_{1: 2}-4.8 \mathrm{eV}\right)$. LUMO $=\mathrm{HOMO}+\mathrm{E}_{\mathrm{g}}$. $\mathrm{T}_{\mathrm{d}}$ indicates the decomposition temperature at a $5 \mathrm{w} \mathrm{t}^{\circ} \mathrm{o}$ decrease.

Table 2. Photoluminescence properties of complexes 1,2 and 3 in different solvents and film states.

\begin{tabular}{|c|c|c|c|c|c|}
\hline \multirow{2}{*}{\multicolumn{2}{|c|}{ Comples }} & \multicolumn{4}{|c|}{$\hat{n}_{\text {werm }}[1 \mathrm{~nm}]$} \\
\hline & & \multirow{3}{*}{$\begin{array}{c}{ }^{a} \mathrm{C}_{2} \mathrm{H}_{5} \mathrm{OH} \\
470,500 \\
0.003\end{array}$} & \multirow{3}{*}{$\begin{array}{c}{ }^{a} \mathrm{CH}_{2} \mathrm{Cl}_{2} \\
472,501 \\
0.006\end{array}$} & \multirow{3}{*}{$\begin{array}{c}{ }^{b} \text { Film } \\
40,500 \\
0.01\end{array}$} & \multirow{3}{*}{$\begin{array}{c}{ }^{b} \text { Film } \\
\text { (in PMMA) } \\
470,499 \\
0.17\end{array}$} \\
\hline & $\lambda_{\text {nriax }}$ & & & & \\
\hline 1 & $\Phi$ & & & & \\
\hline \multirow{2}{*}{2} & $\lambda_{\text {тा1ах }}$ & 452,481 & 452,481 & 455,483 & 451,480 \\
\hline & $\Phi$ & 0.002 & 0.013 & 0.01 & 0.18 \\
\hline \multirow{2}{*}{3} & $\lambda_{\text {тा1аx }}$ & 450,477 & 449,476 & 450,451 & 469,444 \\
\hline & $\Phi$ & 0.012 & 0009 & 0.01 & 0.09 \\
\hline
\end{tabular}

"Same as amotation a and b in Table l. "Iridium complexes were 5 wton doped in PMMA: a thin film of $\sim 10^{-2} \mathrm{M} 9.10$-diphenylanthracene in poly (methy l methacr late) (PMMA) was used as the standard $\left(\Phi=83^{\circ} \mathrm{o}\right.$ ) for calculating $\Phi$ of the films. ${ }^{19 d}$

to-ligand charge transfer $\left({ }^{1} \mathrm{MLCT}\right)$ transitions. ${ }^{19}$ The ${ }^{1} \mathrm{MLCT}$ transition in complex 1 was $\sim 20 \mathrm{~nm}$ longer than those of complex 2 and 3 . indicating that fluorination on the phenyl ring lowered the HOMO energy' level of the iridium metal as a result of decreasing the electron density of the phenyl group.

The PL spectra of the complexes showed emission bands in the range of $4+8-500 \mathrm{~nm}$. exhibiting vibronic progressions with two maximum peaks. This observation indicated that the intra-ligand (IL) ${ }^{3} \pi-\pi^{*}$ contribution was dominant to the luminescent emission ${ }^{20}$ The maximum emission wavelengths $\left[\hat{\lambda}_{13 \mathrm{stmax} .} \lambda_{\mathrm{n} \text { nd.max. }}\right]$ were $[470.500 \mathrm{~nm}] .[+52.48 \mathrm{l} \mathrm{nm}]$ and $[4+9$. $476 \mathrm{~mm}]$ in the blue region for complex 1.2 and 3 . respectively. The emission maxima of 2 were $13 \sim 18 \mathrm{~nm}$ blue-shifted compared to a reported blue light enitter. iridium(III) bis [2-(2,4-difluoro-phenyl)py ridinato](2-picolinate). [FIr(pic), $\lambda_{\text {mix }}=470$. $494 \mathrm{~nm}]^{21}$, reflecting that the $\pi$-accepting character of the phosphine group increased the associated MLCT energy levels. resulting in a blue-shift emission. ${ }^{6}$ The substituents in the main ligand showed a hypsochromic shift on the order of ppy $\rightarrow$ $\mathrm{dfppy} \rightarrow \mathrm{dfmppy}$ and revealed that difluorination on the 2.4-positions of the phenyl ring led to a significant blue-shift, whereas methylation on the py ridine group caused a small blue-shift of the emission maximum. 2

The emission peaks were next examined in a variety of solvents. but little solvatochromism was observed as shown in Table 2. Although the emission in the film state ( $5 \mathrm{wt} \%$ doped in PMMA) was also similar to those in the solution state the quantum efficiency $\left(\Phi_{\mathrm{p}}\right)$ in the film state was enhanced enormo- usly. For example, $\Phi_{\mathrm{pl}}$ in chloroform $(0.004)$ increased up to 0.17 in the film state for complex 1 . The host materials increased the distance between the guest materials. leading to a decrease in the quenching effect. ${ }^{23}$

Electnochemical and Themal Properties. The electrochemical properties were investigated by cyclic voltanmetry (CV) with the resulting data relative to a ferrocenium/ferrocene redox couple $^{2-}$ are in Table 1. All the complexes showed irreversible oxidation potentials in the range of 0.90 to $1.19 \mathrm{~V}$, believed to originate from the iridium metal cationic site together with a contribution from the cyclometalated phenyl fragment. ${ }^{25}$

From the obtained oxidation potential and the absorption edge of the UV-Vis spectrum. the HOMO and LUMO and the energy gap $\left(\mathrm{E}_{\mathrm{g}}\right)$ were calculated. The results are listed in Table 1 . The oxidation potential of complex 2 was $1.19 \mathrm{~V}$ shifted cathodically by $0.29 \mathrm{~V}$ conpared to the complex 1 . Fluorination on the phenyl ring decreased both HOMO and LUMO energy levels. but the significant lowering of the HOMO energy level caused a widening of the energy gap $\left(\mathrm{E}_{g}\right)$, resulting in a blue-shift of the emission maximum. Methylation on the py ridine ring increased the HOMO energy level by $0.04 \mathrm{~V}$ and the LUMO energy level by $0.07 \mathrm{~V}$.

The thermal stability, investigated using thermal gravimetric analysis (TGA), showed that the $5 \%$ (wt.) decomposition temperatures were above $370^{\circ} \mathrm{C}$ (Table 1). exhibiting the high thernal stability required for an electroluminescent device.

\section{Conclusions}

Three blue phosphorescent cationic heteroleptic cyclometalated iridiun(III) complexes. containing phenylpy ridine derivatives in combination with a newly designed 2-[(dipheny.lphosphino)methyl]pyridine (dppnp) ligand, were prepared. It was revealed that the ancillary dppmp ligand played an important role in tuning the enission color and led to a blue-slift emission due to the $\pi$-acceptor ability of the phosphorous atom in the dppnip. In particular, [(dfmppy) $\left.)_{-} \operatorname{r}\left(\mathrm{P}^{\wedge} \mathrm{N}\right)\right] \mathrm{PF}_{6}$ could be a novel candidate for application in optoelectronic devices for blue emission.

Supplementary Data CCDC No. 633532 contains the supplementary crystallographic data for [(dfmppy $)_{2} \operatorname{Ir}(\mathrm{dppmp}) \mathrm{PF}_{6}$. These data can be obtained free of charge via http://nww.ccdc. cam.ac.uk/conts/retrieving.html, or from the Cambridge Crystallographic Data Centre. 12 Union Road, Canbridge CB2 1EZ, UK: fax: (+44) 1223-336-033: or e-mail: deposit $a$ ccdc.cam. ac.uk. 
Ackonowledgments. This research was supported by the MKE (The Ministry of Knowledge Economy). Korea. under the ITRC (Information Technology Research Center) support program supervised by the NIPA (National Industry Promotion Agency, NIPA-2009-(C1090-0902-0022)). X-ray data were collected at the center for Research Facilities in Chungnam National Universitỹ

\section{References}

1. Baldo, M. A.; Lamansky, S.; Burrows, P. E.; Thomson, M. E.; Forrest, S. R. Appl. Phys. Lett. 1999, 75, 4.

2. (a) Tsuboyana, A.: Miura, S.: Takaguchi, T.: Okada, S.: Hoshino, M.; Ueno, K. J. An. Chent. Soc. 2003, 125, 12971. (b) Gong, X.; Ostrowski, I. C.; Bazaw, G. C.; Moses, D.; Heeger, A. J. Appl. Phss. Lett. 2002, 81, 3711. (c) Ionkin, A. S.: Wantg, Y: Marshall, W. J.: Pertrov, V. A. J. Org. Chem 2007, 692,4809. (d) Park, G. Y.: Ha, Y. Sin. Afetals 2008, 158, 120. (e) Xiao, G.: Lei, P.; Chi, H.; Lu, Y.; Dong, Y.; Hu, Z.; Zhang, Z.: Li, X. Sinf. Afetals. 2009, $159,705$.

3. (a) Lee, S. I.; Park, J, S.; Song, M.; Yoon, K. I.; Kin, Y.-I.: Jin, S. H., Seo, H. T. Appl. Phys Lett. 2008, 92, 193312 . (b) Bolink, H. I.: Coronado, E.; Santamaria, S. G.; Sessolo, M.; Evans, N.: Klein, C.: Baranofif, E.: Kalyanasundaram, K.: Graetzek, M.: Nazeernddin, M. K. Chem. 2007, 3276. (c) Huang, W. S.; Lin, I. T.: Lin, H. C. Organic Electronics 2008, 9.557. (d) Zhou. G.: Ho, C. L.: Wong, W. Y:; Ma, Q. W.: Want, L.: Lin, Z; Marder, T. B.: Beeby, A. Adv Funct h later 2008, IS 499

4. (a) Lee, S. J. Park, J. S.; Yoon, K. J.; Kim, Y.-I.; Tin, S. H.; Kang, S. K. Gal, Y. S.: Kang, S. W.: Lee. J. Y.: Kang, J. W.: Lee, S. H.: Park, H. D.: Kimn, T. I. Adt Fmct M Hater 2008, 18, 3922 . (b) Lo, S. C.; Richards, G. I.; Markham, J. P. T.; Namdas, E. B.; Shamn, S. Bum, P. L.; Samuel, I. D. W. Adv Funct. Afater: 2005, 15, 1451. (c) Takizawa, S. Y.; Echizen, H.; Nishida, J.; Tsuzuki, T.; Tokito, S.; Yamashita, T. Chem. Lett. 2006, 35, 748. (d) Yang, C. H.: Cheng, Y. M.: Chi, Y:; Hsu, C. H.; Fang, F. C.; Wong, K. T.: Chou, P. T.; Chang, C. H.; Tsai, M. H.; Wu, C. C. Angew: Chent. Int Ed. 2007, 46,2418 .

5. Adachi, C.; Baldo, M. A.: Forrest, S. R.; Thompson, M. E. Appl. Phvs. Lett. 2000, 77,904.

6. Chiu, Y. C.; Chi, Y; Hang, J. Y.; Yl, Y. C. Chung, M. W.; Lee, G. H.; Chou, P. T.; Chen, C. C.; Wu, C. C.; Hsieh, H. Y. ACS Appl. Mater Interfaces $\mathbf{2 0 0 9}, 1,433$

7. Mivaura, N.: Suzuki, A. Chem. Rev. 1995, 95, 2457.

8. SMART, V 5.05 Sottware for the CCD Detector Sy stem: Bruker
Analytical X-ray Systems. Ine: Madison. WI 1998.

9. SAINTPLUS, V 500 Software for the CCD Detector System; Bruker Analytical X-ray Systems. Inc.: Madison. WI 1998.

10. SADABS. Program for absorption correction using SMART CCD based on the method of: Blessing, R. H. Acta. Crystallogr. A 1995, 51. 33 .

11. Sheldrick. G. M. SHELXTL, V 6.1: Bruker Analytical X-ray Systems, Inc:: Madison, WI 1997.

12. Nonoyama, M. Bull. Chem. Soc. Jpm. 1974, 47,767.

13. Lamansky, S; Djurovich, P; Murphy, D; Abdel-Razzaq, F.; Kwong, R.; Tsyba, I.: Bortz, M.; Mui, B.: Bal, R.; Thompson, M. E. Inorg. Chem. 2001, 40, 1704.

14. (a) Orselli, E.: Kotlas, C. S.; Konradsson, A. E.; Coppo, P.; Frhlich, R. Cola L. D.: Dijken, A.: Bchel, M: Bner, A. Inong. Chem 2007, 46. 11082 (b) Mak. C. S. K.: Hayer. A.: Pascu. S. I.: Watkins. S. E.: Holmer, A. B.: Köhler, A.; Friend, R. H. Chem. Commun. 2005 , 37,4708 .

15. Tamayo, A. B.; Allevne, B. D.; Djurovich, P. I.; Lamanshy, S.; Tsyba, I.: Ho, N. N.; Ban, R.; Thompson, M. E. J. Am. Chem. Soc. 2003. 125.7377.

16. Wu, L. L.; Yang, C. H.; Sun, I. W.; Chu, S. Y; Kao, P. C.; Huang. H. H. Orgnontetallics $2007,26,2017$.

17. Hunter C. A.: Sanders, K. M. J. Am. Chem. Soc. 1990, 112, 5525.

18. (a) Goldsmith. J. I.: Hudson, W. R.: Lowry, M. S.: Anderson. T H.; Bemhard, S. J. Am. Chent. Soc. 2005, 127, 7502. (b) Joshi, H. S.; Tamshidi, R, Tor, Y. Angew: Chem. Int Ed. 1999, 38, 2721. (c) Fang, K. H.; Sur, I. W. horganic Chinica Acta 2006, 359,441 . (d) Zhang. X.: Shetty, A. S.: Jenekhe. S. A. M Iacromolecles 1999 , 32,7422 .

19. Tavasli, M.; Bettington, S.; Pezepichka, I. F.; Batsanov, A. S.; Bryce, M. R.; Rothe, C.; Monkman, A. P. Eut J. horg. Chem. 2007, 4808

20. Lamansky, S.: Dịrovich, P.: Murphy, D.; Abdel-Razzag, F.: Lee, H. E:; Adachi, C.; Burrows, P. E.; Forrest, S. R.; Thompson, M. E. J. An. Chent Soc. 2001, 123,4304

21. Adachi, C.; Kwong, R. C.: Djurovich, P; Adamovich, V.: Baldo, M. A.: Thompson, M. E.; Fonest, S. R. Appl Phys. Lett. 2001, 79, 2082.

22. Xu, M; Zhou, R.; Wang, G.; Yu, T. Horg. Chenti Acta 2009, 362 , 2183

23. Namdas, E. B.; Ruseckas, A.: Samuel, I. D. W.: Lo, S. C.: Burn, P. L. J. Phus. Chem. B 2004, 108,1570

24. Pommerehne, T.; Vestweber, H.; Guss, W.; Mahrt, R. F.; Bassler, H.: Proseh, M: Daub, J. Ads: Mater: 1995, 7, 551

25. Lowry, M. S.: Bemhard, S. Chem. Em: J. 2006, 12, 7970 